\title{
1959 Institute for California Judges-Panel Discussion, Part I: Preliminary Matters and Trial Proceedings
}

The California Law Review presents herewith the first of a series of panel discussions presented at the Institute for California Judges, in the hope that their presentation in printed form will expand their usefulness to the participants and make them available for the first time to the bar in general. The Institute was conducted under the sponsorship of the Conference of California Judges and the School of Law, University of California (Berkeley), June 15-17, 1959, in the Moot Court Room of the School of Law. Future issues of the Review will carry panel discussions on "Selecting the Jury" and "Instructing the Jury," which were also given at the Institute. Participants in the panel on "Preliminary Matters and Trial Proceedings," presented below, were as follows:

The Honorable Paul Nourse, Judge of the Superior Court, Los

Angeles County

Stevens FARgo, Attorney at Law, Los Angeles

David W. Louisel, Professor of Law, School of Law, University of California, Berkeley

Most of the questions considered by the panel members were presented from an agenda. The concluding questions, where noted, were submitted from the floor by the judges participating in the conference. The record of the proceedings was edited by Thomas $H$. Gee of the California Law Review staff.

QUESTION: Should the trial judge, on the record outside of the presence of the jury, pre-try questions of law and particularly questions as to the admissibility of evidence that will arise during the trial?

JUDGE NOURSE: My answer to this is an unqualified yes. Under pretrial procedures the pre-trial judge, with regard to the matter of evidence, can do little more than obtain stipulations as to foundational matters. He is in no position to rule as to any competency, materiality, or relevancy of the evidence. On the other hand, the trial judge, after he has familiarized himself with the issues, either as formed by the pre-trial order or the pleadings and the pertinent law, is frequently in a position to rule in advance of the trial as to the admissibility of evidence. In my opinion these pre-trial conferences by the trial judge should be informal up to the time the court is ready to rule and sustain an objection. When that point is reached, he should immediately go on the record; if the evidence as to which the objection is being sustained is documentary, he should cause it to be marked for identification; if the objection is as to testimony, he should require a proper offer of proof to be made and the objection to be stated so that the ruling will go into the record. In either case he must then obtain a stipulation that 
this pre-trial record is deemed to have been taken during the progress of the trial and will be incorporated into the record of oral proceeding.

MR. FARGO: I think most trial lawyers welcome this informal meeting that Judge Nourse has spoken of, and it should be desirable from the trial judge's standpoint as well, since it acquaints him with the degree of preparation of counsel. It does not seem to me at all out of order for the trial judge, in many cases, to direct some memorandum to be filed with him or some further preparation or foundation to be brought in. Regarding this advance ruling on matters of admissibility, a question often raised is the extent to which a trial judge ought to go in preserving a record for the man against whom he rules. For example, someone presents his proposed bit of evidence, the judge makes his ruhing, and there is either an insufficient offer of proof or an insufficient objection to it. Should the judge then go ahead and say, "Now, here, Mr. Jones, perhaps you'd better voice your objection a little more to the point so you've got some kind of a record," or "There should be a fuller presentation of offer?" Speaking as a lawyer, I think that the judge ought to regard the matter as an adversary proceeding. I do not see any duty upon the trial judge either to preserve a possible reversal for himself or for the successful lawyer.

PROFESSOR LOUISELL: I am in general agreement as to the desirability of this pre-trial discussion in the trial judge's chambers about as many of the issues as feasibly can be taken up, particularly respecting the admissibility of evidence. But I can conceive of a judge overdoing this type of pre-trial. Sometimes it seems to me that problems of admissibility really will not unfold adequately except during the course of the trial itself. As to some questions, where admissibility may involve a problem of remoteness for example, and where there will be a big element of discretion in the trial judge, it seems to me there may be instances where the lawyer would be justified in saying, "Well, if your honor will pernit, I would rather have this issue deferred until it reveals itself during the course of the trial." That is the only qualification that I would make, because I thoroughly agree that within certain limits, a judge can make the course of a jury trial much smoother by having this informal conference before the commencement of the trial.

JUDGE NOURSE: I did not want to be understood as saying the court should require these things to be passed upon, but rather that the court should influence counsel to present these problems where clearcut questions of admissibility of evidence are concerned which do not depend upon the development of other evidence. 
QUESTION: Do you have any ideas about setting the rules or establishing the climate for the trial?

JUDGE NOURSE: I think you are all familiar with the advocate who in a non-jury trial is peaceful and does not indulge in any histrionics, but the minute the first juror's drawn, he becomes a ham actor. He thinks he cannot serve his client unless he is belligerent, wise-cracking, indulging in personalities with counsel and raising issues that are not within those framed by the pleadings. This leads many times to a prolonged trial, to the jurors following a red herring and to a verdict reflecting not the jury's true findings upon the issues involved but their like or dislike of someone in the courtroom.

To prevent this, I have a procedure of admonishing counsel as to the ground rules in advance. I advise that I will not permit counsel to address each other during the trial and in the presence of the jury; that they will state all their objections to the court and that there will be no arguments on objections unless asked for by the court; that they will offer stipulations to the court and the opposing counsel may either accept or reject them or ask for a conference to state some conditions or additions to it; that there will be no wise-cracking and that they will conduct their examination of witnesses from their place at counsel table unless they first secure the permission of the court to examine from some other place. Of course, there are many instances when counsel must leave the counsel table but he should first receive the permission of the court. I also inform them that on their voir dire examination they will refrain from covering any matters covered by the court in its examination and will direct their questions only to matters which would be the basis for a challenge for cause, and they will not examine as to matters of law, and that in making their opeming statements, they will refrain from argument, confine themselves to the outline of the facts they intend to prove, and stay within the issues framed. Although I have had some pretty tough advocates before me, I have never had one that I thought intentionally broke the ground rules, and they have been nearly unanimous in saying they would much rather learn the ground rules before the trial than to be adinonished in the presence of the jury by the court for doing something they had not been told about in advance.

MR. FARGO: I think most lawyers are glad to get the judge's ideas, and I think we would be mighty glad too to have the judge stick to his ground rules. In other words, if the other fellow transgresses, let the judge lower the boom on him. There is one feature of what Judge Nourse says that I think has to have a very liberal interpretation. I think the trial lawyer is entitled to the freedom of the courtroom so long as he does not make a jumping jack or a nuisance out of himself. I personally believe very strongly that in some matters a lawyer can make much more pointed use of his mate- 
rial if he can move about. For instance, the impeachment value of a deposition or a signed statement or a facsimile of a police report is tremendously increased if it is presented to the witness being cross-examined so that his signature, his initials and his changes can be admitted so that you can take him right down the line and find out the whole thing is true except the crucial bit. You know how eloquent that type of a cross-examination is, and you can not do that from the counsel table. Another thing we must not lose sight of is the acoustic problem; it is very effective for counsel to interrogate from the end of the jury box if he has one of those witnesses that you just can not get much noise out of.

PROFESSOR LOUISELL: I agree that there has to be that reasonable latitude of movement to trial counsel in the courtroom. But subject to that, the important problem is to avoid a badgering position over the witness.

I think, Judge, you hit the touchstone of the problem of the orderliness of a trial when you stated that all remarks should be addressed to the court. It is pretty hard to bicker with opposing counsel when you have to do it through the intermediary of a third person, particularly when he is a judge.

QUESTION: What do you think about the trial judge trying to reach a settlement in his informal pre-trial conference?

JUDGE NOURSE: I do not know of any case which is not worth a try. If you can get counsel to frankly discuss the issues and what evidence they have, there is a good chance that a case can be brought to settlement without the first juror being drawn. I think you should not abandon the possibility of settlement even at that time. The evidence clevelops and you hear what counsel have to say and you can see that the evidence is going against one fellow. You know that he is a little afraid to show weakness by opening the possibility of settlement, so you can open it up by saying, "Now, you want to think this over a little further?" and you can get negotiations going again. I think you have all had the experience, even after the jury has left the room, of starting a little more discussion and finding you have it settled.

MR. FARGO: I do not recall of ever hearing a trial judge criticized by the lawyers for inviting settlement discussion to continue. If we divide the trial counsel in these damage suits-I think we are talking mostly about theminto the experienced and the relatively inexperienced kind, I think there is an advantage in either class for the judge reawakening settlement discussion. The experienced fellow will certainly not resent it, and there are a lot of attorneys who just are not very good at evaluating a case, and to whom the trial judge with the objective viewpoint which the bench job can give him can say in a fatherly way, "Now, Mr. So-and-So, I just want you to know what I think about your demands here," and bring him down to size. 
Further, a trial judge can temper the courageous advocate who believes in his case and is going, just by his nature, to listen with a more willing ear to the good stuff that comes out and sift out the part that does not help him so much. I think the time is never too late for a trial judge to keep his door open as an agent for reopening settlenient negotiation.

PROFESSOR LOUISELL: It helps also, of course, with stubborn clients to be able to tell them what an experienced judge thinks about the case, at least what counsel gathers he thinks about it. I do think judges should remember that the degree to which they are justified in nrore or less-I won't say coercing-but more or less encouraging settlement, is dependent upon how much time they have had to think the case through and appraise it. In other words, what the lawyers appreciate and what is really helpful is not an off-the-cuff opinion, but a deliberate opinion from the judge. With that qualification, and I do not think it is even a qualification, I would thoroughly agree with what you have said.

JUDGE NOURSE: I never thought I could express an opinion as to the amount of settlement, but I have found it helpful to point out to counsel the weaknesses that have developed in the case he thought he had and let him carry on from there.

MR. FARGO: While on the subject of settlements, I would like to tell of the experimental steps we have taken in trying to reach settlements of personal injury damage suits at the formal pre-trial conference down in Los Angeles. We have been having the plaintiffs and the superintendent of claims for the insured defendant come in personally and the pre-trial judge finds how far apart the parties are and then expresses his opimion as to whether the demands are proper. He reads over the medical reports of both sides, and he goes way out, telling them what he thinks the claim is worth with the plaintiff sitting there. There is no reticence here, and we have been getting from two-thirds to three-fourths of the personal injury calendar settled at pre-trial. This attempt to reach settlement was compulsory during its experimental stage, but it is now elective. I think if it results in the percentage of settlements we have been getting in the experimental stage, it is going to be a popular thing.

QUESTION: Should the court interrupt counsel during his opening statement, and how far should it control interruptions by opposing counsel?

JUDGE NOURSE: I think that if in chambers counsel have been warned not to bring argunentative matter into their opening statement, to stay within the issues, and to confine themselves to a statement of what they intend to prove, and if the jury has been adnonished before any opening statement is made, that these statements of counsel are not to be accepted 
as evidence and that their sole purpose is to enable the jury to fit each piece of evidence into the pattern which counsel hopes to develop, it is very seldom that either of these questions will arise. But if counsel should get out of the straight and narrow path, in my opimion the trial judge should not wait for objection from opposing counsel but step in right then and say, "Counsel, please do not indulge in argument." If the court does not step in, then, of course, opposing counsel may; but one place where opposing counsel come in and where they have no business to do so is with objections that their opponents can not prove what they say they will prove. As long as what counsel states he is going to prove is material and relevant and the evidence by which he states he will prove it is competent, it makes no difference if opposing counsel thinks the other fellow cannot produce the evidence to do it.

MR. FARGO: I think the best remedy to these extravagant claims of proof is that if the counsel does not prove it, his opposing counsel has a very definite and powerful weapon in his closing argument. He can charge bad faith and probably with pretty good reason. The matter of the trial judge taking charge of the opening statements is one that I think is neglected too often. It is a hard thing for a trial lawyer to stand up and make an objection to an opening statement, and personally I shrink from doing it. One thing in these opeming statements I would like to see limited is the tendency counsel on both sides of damage suits seem to have of making argumentative statements about how negligent their opponents are. The assertion that an act amounts to recklessness, even wantonness, or that a hole three feet wide and six inches deep is a trap is argument. If I were writing the rules I would have the trial judge both in the preliminary conference and if necessary during the opening statement bear down on that kind of inflammatory material.

PROFESSOR LOUISELL: I would just like to enter a plea for a little indulgence for the young and inexperienced lawyer because try though I do to teach that the function of an opening statement is to state what the evidence will show and not to argue, it seems almost impossible to get that idea across. With the young lawyer, at least, I hope the first reprimand will be a relatively mild one.

QUESTION: When should the demand for a separate trial of affirmative defenses be made?

JUDGE NOURSE: Unquestionably, it should be made before the jury is drawn, and preferably in the trial judge's informal pre-trial conference; because if the separate trial is granted, counsel will examine on the voir dire only as to the issues pertinent to the affirmative defense since that is all the 
jury is going to then hear. Further, in their opening statements, they will deal solely with the facts regarding the affirmative defense and need only call those witnesses necessary for the trial of these defenses.

MR. FARGO: I could not find anything in section 597 of the Code of Civil Procedure $^{1}$ or any cases that say when you have to make a motion for the separate trial of an affirmative defense. The practice I thought most lawyers followed was to make a regularly noticed motion in advance of the trial. I do not know that any court insists upon such a motion being inade but certainly it makes sense to have it done that way.

PROFESSOR LOUISELL: It certainly seems to me that the last suitable time to make this motion under section 597 of the Code of Civil Procedure is just before the drawing of the jury-that is the last feasible time.

QUESTION: If the separate trial as to the affirmative defense is granted and the jury determines against the defendant, should the same jury be used to try the issues in chief?

JUDGE NOURSE: The answer to this depends a great deal upon the nature of the special defense to be tried. Since 80 to 90 percent of our cases are personal injury cases, usually the special defense will be either the giving of a release or the statute of limitations. If the defense is that of a release being given, in most cases, the settlement will have been made by an insurance company, so the fact of insurance will be brought out. In some cases the amount of insurance will be stated, and if the settlement was substantial at all, it will, in effect, let the jury know of an offer of compromise, and the jurors are very likely to conclude that this was an admission of liability. Each of these defenses is often founded on facts which might just as well be called proof of fraud. If the jury finds against the defendant on such a defense, and then goes to the trial of the chief issue, I do not care what admonition you give, you are never going to make it beheve that the fraud of this defendant or the insurance company had nothing to do with the issue of liability or the amount of damage. It seems to me that in those cases, a separate jury slould be drawn. However, when it is apparent that there is little likelihood that a jury will find in defendant's favor on an affirnative defense, I then give defendant a chance to abandon his defense or try the whole case at once. It is just a stall for time. I also favor a single trial where

1 Cax. Code Crv. Proc. \$ 597: "When the answer pleads that the action is barred by the statute of limitations, or by a prior judgment, or that another action is pending upon the same cause of action, or sets up any other defense not involving the merits of the plaintiff's cause of action but constituting a bar or ground of abatement to the prosecution thereof, the court may, upon the motion of either party, proceed to the trial of such special defense or defenses before the trial of any other issue in the case .... The provisions of this section shall also apply to the trial of special defenses pleaded in an answer to a cross-complaint ...." 
the statement of evidence shows that upon the trial of the affirmative issue, all of the evidence except that regarding damages will probably be brought out. You are going to have all the evidence that goes to liability, and it seems a useless thing to have all that evidence heard twice from witnesses who can not tell just exactly the same story and are bound to be impeached by the little variations in testimony given in the two trials, so that the second trial is dragged out.

MR. FARGO: I agree with you, Judge Nourse, that we ought not to waste a lot of time on a very weak affirmative defense, but if there is any substance at all in an affirmative defense, I think you must have separate juries and separate trials. You can not expect a jury trying the issue of liability to erase from its mind the evidence it would hear on trial of a release. In some cases I do not think you are going to get a fair trial on the separate issue of the release if you have the same jury do it. Take a case where the plaintiff has lost a leg, for instance, something which has a very strong appeal to sympathy. You know from your own experience that jurors are very loathe to give effect to a release that might well be properly upheld if they did not have before them the evidence of the severe loss.

JUDGE NOURSE: What I had in mind was the release from a hospital bed given for $\$ 500$ about 2 days after an accident involving loss of a leg. As a judge, I would know you were not going to win on that, and I would either let you abandon it or go ahead and have a single trial.

MR. FARGO: I would do the same thing if I were the judge because you know perfectly well that thing is not going to stand up. Any defense lawyer with any experience and with any stature with his client will abandon that thing before he ever gets into court. $\mathrm{He}$ is not so stupid that he would want the release known.

\section{QUESTION: Should witnesses be excluded on motion?}

JUDGE NOURSE: I think each case present its own problems. You can first consider whether there is any place the witness can stay while he is waiting around 2 or 3 days to be called. In most instances I have seen where exclusion of witnesses was requested, I saw no real basis for granting the motion.

MR. FARGO: I think it is ridiculous to exclude witnesses in a damage or tort case. In the first place, you can not keep vitnesses who have been excluded from talking to those who have testified or to parties who have heard them testify. Secondly, I think that it would be absurd to think that the lawyer, intending to call them, would not talk to them about their testimony before they testify. Furthermore, witnesses to a sudden happening, like a 
tort, an accident case, in all honesty, are going to have different versions in slight particulars. If you exclude them, you find the cross-examining lawyer taking up a lot of extra time, not proving a thing but going over shight differences in detail. I think a trial judge ought to discourage exclusion of witnesses in the average case because I do not think it accomplishes any furtherance of justice.

PROFESSOR LOUISELL: I agree that it is a much exaggerated motion. I suppose there can be cases where a particularly dull witness, who really wants to lie, can be helped in his perjury by being in court when the other witnesses are testifying. But in general, I think it is a wasted effort to exclude.

QUESTION: Can the court keep the plaintiff from calling the defendant as a witness under section 2055 of the Code of Civil Procedure ${ }^{2}$ until by other evidence he has established a prima facie case?

JUDGE NOURSE: It never occurred to me that the court had any such power, and I was surprised to find that the district court of appeals in two districts has held that the trial court did not abuse its discretion in so doing. The cases are: Land v. Del Mar Turf Club ${ }^{3}$ and Fuchs v. Southern Pacific Co. ${ }^{4}$ However, I am pleased to say that a recent case in the third district, Murry $v$. Manley, ${ }^{5}$ holds that the court has no such power. Under section 2042 of the Code of Civil Procedure ${ }^{6}$ the court has the power to direct the order of proof, and therefore may insist that a witness for whose testimony a foundation is needed be called in the proper order, although it may waive that upon the statement by counsel that he will establish the foundation. But I know of no law except those two cases which I mentioned that says the court can step into the shoes of counsel and tell him how he is going to prove

${ }^{2}$ CAL. Code CIV. Proc. $\$ 2055$ : "A party to the record of any civil action or proceeding or a person for whose immediate benefit such action or proceeding is prosecuted or defended, or the directors, officers, superintendent, member, agent, employee, or managing agent of any such party or person, or the agent, officer or employee of a mumicipal corporation which is a party to the action or proceeding, may be examined by the adverse party as if under cross-examination, subject to the rules applicable to the examination of other witnesses. The party calling such adverse witness sliall not be bound by his testimony, and the testimony given by such witness may be rebutted by the party calling him for such examination by other evidence. A party, when so called, may be examined by his own counsel, but only as to the matters testified to on such examination. A witness other than a party, when so called, may be cross-examined by counsel for a party adverse to the party calling such witness, but only as to matters testified to on such examination."

3120 Cal. App. 2d 829, 262 P.2d 54 (1953).

45 Cal. App. 2d 409, 42 P.2d 704 (1935).

5 170 A.C.A. 393, 338 P.2d 976 (1959).

6 CaL. Code CIv. Proc. $\$ 2042$ : "The order of proof must be regulated by the sound discretion of the court. Ordinarily, the party beginning the case must exhaust his evidence before the other party begins." 
his case or by what witnesses. In fact, I do not see why plaintiff can not prove his case under the testimony of the defendant alone-call him as his only witness.

PROFESSOR LOUISELL: There is certainly nothing in section 2055 that inhibits counsel in picking his own time to call the opposing party. I hope that this latest case Judge Nourse mentioned does settle it, or that the supreme court will do so.

QUESTION: Should the court explain to the jury the reason for hearing argument outside the presence of the jury?

JUDGE NOURSE: I see no reason to explain; just tell the jury that the court is going to take a recess to discuss with counsel matters of law that are of no interest to the jury. That ends it. Otherwise you go into a long line of reasoning that does not seem to me to be called for.

MR. FARGO: I think there is every reason why a judge should not make any explanation of why there has to be a conference. I think a lot of judges are inclined to forget the enormous impact of the slightest comment of the judge on the jury, i.e., how closely the jurors seem to follow any expression or any intimation by a trial judge. I have had a number of lawyers complain to me that they have felt that an adverse result came about by too much explanation by the judge. The jury ought to be smart enough to know that the judge and the lawyers are doing their job without getting an explanation of how they are doing it.

PROFESSOR LOUISELI: The reason that the right to comment to the jury was urged so strongly a number of years ago and finally at least theoretically accepted in Cahifornia in 1934 was the very fact, as Mr. Fargo points out, that the juror is so inclined to look to the judge for indirect indications of how he feels about the merits. It is miuch better to have the judge in the position of frankly commenting on the evidence.

\section{QUESTION: Should the trial judge explain his rulings?}

JUDGE NOURSE: I think there are certain instances in which the trial judge should explain his rulings. Of course, in our instruclions we always tell the jury that they are not to speculate as to what the evidence would show if the objection had not been sustained, and that they are not to pay any attention to evidence which has been stricken. I have found it best at the first opportunity during the trial to make that very clear to the jury before they have started to speculate. As to the matter of striking out evidence, we all know they can not erase it from their minds, but if at the time that evidence is first stricken, you make it clear that it is outside the issues, I think it has more effect. The problem of explanation also arises where 
there is more than one defendant and a non-suit is granted as to one of them. The court should go to great pains to make it clear to the jury why it has granted the non-suit and that there was no question of fact left for the jury to determine. Most important, the jury must be made to understand that the fact the court has let one defendant out has no bearing on the question of liability of the others and that this question of fact remains for the jury. If you do not do that, the jury can be very well misled by the knowledge that one defendant has been discharged.

MR. FARGO: I think what the trial judge says is a matter of great delicacy. I have seen the trial judge say nothing as one of the defendants disappeared out the back door with his brief case in hand-it would take a pretty stupid juror not to draw a few surmises from that. On the other hand, when the judge gives the instruction which Judge Nourse suggests, it has to be done very clearly with a great deal of forethought not to leave an inference one way or the other. I think generally the less said by the judge about a ruling, the better off everybody is.

PROFESSOR LOUISELI: This reference to the impossibility of erasing from the mind what has already been registered there reminds me of certain results of the University of Chicago Jury Studies. If there is any one thing that they tend to establish with a high degree of probability, it is the fact that the precautionary instruction achieves little except to accentuate in the mind of the jury the evidence that is being stricken. I think that the studies are sufficiently authoritative so that the trial lawyer might often now liesitate to make a motion for a precautionary instruction for fear that it is just going to accentuate the thing that he wants the jury to forget. For example, a reference to insurance improperly creeps into the case and the judge turns to the jury and says, "Members of the jury, you are completely to ignore any reference to insurance. No insurance company is a party to this case," and so forth. What does that accomplish with the jury? The notion of the Chicago Jury Study is simply that it accentuates in the jury's mind that there is insurance. Those studies are still somewliat tentative; eventually I think there will be some very interesting articles and perhaps a book on their significance.

JUDGE NOURSE: Another matter on this question of explanation-I have had many attorneys call an adverse witness under section 2055 of the Code of Civil Procedure and say, "Would your honor instruct the jury as to the meaning of calling a witness under section 2055 ?" I've always refused to do so. Section 2055 gives the right to call an adverse witness and question him as if on cross-examination, and it also gives the right to impeach him by 
any means available for use in impeaching a witness called by the opposing party. If there is an objection that a question to such a witness is leading when counsel has a right to lead as on cross-examination, I dispose of it as a question of law in overruling the objection. There is nothing to explain to the jury. If the objection is to the impeaching evidence, you rule on that and that raises solely a question of law. But counsel still seem to think that you should tell the jury in the words of the statute that he is not bound by that witness's testimony. In my mind, that is error. Whether that testimony was elicited under section 2055 or otherwise, counsel is bound by it if the jury believes it, and it will support a verdict. I call your attention to Daniels $v$. City and County of San Francisco. ${ }^{8}$ Such testimony is evidence and counsel is bound by it if the case goes to the jury. He is not bound by it on a motion for non-suit or a directed verdict with one exception which Professor Louisell will discuss. As far as I can see, there is no reason for the court to explain anything about section 2055 to the jury.

PROFESSOR LOUISELL: A recent interesting case is Leonard v. Watsonville Community Hospital, ${ }^{9}$ a malpractice case in which a divided supreme court held that at the end of the plaintiff's case one of the doctors sued was entitled to non-suit essentially because the other doctors sued had given testimony, when called under section 2055 , that completely exculpated the doctor given the non-suit. The majority of the court made it very clear that as far as the jury is concerned, it is of no consequence that evidence is received under section 2055 rather than some other way. The majority also pointed out that where evidence comes in under section 2055 and pertains to an inference, that evidence is pertinent on a motion for a non-suit despite the general rule that Judge Nourse has stated. In other words, when a motion is made for a non-suit, the plaintiff's case up to that point having depended upon the inference of res ipsa loquitur, the problem is to determine whether such inference is disproved as a matter of law; the judge may consider the evidence under section 2055 for that purpose in deciding whether to grant or deny a non-suit.

JUDGE NOURSE: In the Leonard case the witness called whose testimony was held to dispel the inference was testifying against his own interest. In other words, Doctor $A$ testified to facts which showed that Doctor $B$ could not have had anything to do with leaving the instrument in there; it did not let $A$ out but it let $B$ out under $A$ 's testimony.

QUESTION: Should reservation of rulings be made in a jury trial?

JUDGE NOURSE: To my mind that is a very dangerous and unfair thing. The objection should be disposed of on its merits at the time it is made if 
possible. If there is doubt as to it, the objection should be sustained, giving leave to reopen if the first ruling is later found to be erroneous. That way you do not let in the evidence and then try to erase it by striking.

MR. FARGO: From a lawyer's standpoint, that is the only way to do, for obvious reasons. It seems to me there will be far less trouble if a trial judge in doubt excludes some topic and later reverses himself than if he lets in a lot of stuff and then attempts to strike it out by admonition. I would certainly exclude unless I was quite clear that the matter was properly in.

PROFESSOR LOUISELL: Of course it is obvious that in cases tried to the court the very opposite philosophy is the order of the day.

QUESTION: What policy do you favor in regard to the partial exclusion of bills and letterheads that disclose the fact of insurance or other matters that should not come to the attention of the jury?

JUDGE NOURSE: As to bills, I have never had any practical problem. I have had no trouble getting counsel to stipulate to the fact that the bill was rendered. Counsel stipulate that it was rendered for a certain purpose and either paid or not paid; the question is left to the jury to determine whether it was reasonable and whether it was necessarily incurred. The bill is kept out of evidence and the facts that have been proved by the bill are in by stipulation. It may be a little more difficult when there is some other type of document that reveals the fact of insurance. I think that is the main problem that arises. The question is how you are going to keep this information out-delete it, paste something over it, have the clerk take a razor and cut it out. This to me is just a practical problem that each judge has to solve for himself as the questions arise.

MR. FARGO: I do not see any problem on bills and that type of document either. But we are getting a great many cases involving accidents related to construction of some sort, in which someone will offer the general construction contract, the specifications under it, every sub-contract with the other parties being sued, and the ordinances involved. Only part of all this is material. I suggest as a fair requirement of the trial judge that there be copied from the ordinances, contracts, and specifications those parts that are supposed to be material and extracts of these offered. They will not be very long in most cases. In most of the cases I see tried, they just bring in these great bundles of ordinances or contracts, toss them up to the judge and offer them into evidence. They do not even mark out the parts they think are material.

PROFESSOR LOUISELL: I think it is a good idea to reduce to a new document the pertinent material. I remember in one case, a libel suit, that 
by the time we got through blocking out the inadmissible items in the newspaper story, we had a ridiculous looking newspaper sheet that could only have inspired the jury to try to read behind the block-outs. It would have been a much better thing to reduce the pertinent parts to another document.

QUESTION: How do you feel about the admissibility of hospital records under the business records rule, Code of Civil Procedure section 1953(f)? ${ }^{10}$

JUDGE NOURSE: I have had an unfortunate experience with hospital records while on the bench, and so when counsel come in with a hospital record, I get them to stipulate to the foundational facts. Then I have the record marked as an exhibit for identification only and tell counsel that when any part of it become relevant they may offer that part. I do this because I think there are many matters in those hospital records that do not fall within the Business Records as Evidence Act; ${ }^{11}$ i.e., they are not a record of either an act, condition or event. My own opinion is that a diagnosis does not come within the act. I had ore case where they got a diagnosis in before I knew better. The diagnosis was of a skull fracture; it turned out it was macle by an internist in a general hospital and what he had diagnosed as a skull fracture was the natural sutures in the head of a child that had not yet filled up with bone. There are other matters in these records that are purely hearsay even under the business records rule. So, get the record in for identification only and then let each piece as it becomes relevant be offered rather than admit the whole thing and then have somebody get before the jury and read something that nobody ever thought was there.

MR. FARGO: I agree that the practical answer to the hospital record problem is to have it marked for identification only. When your experts need it, maybe they rely on an $\mathrm{X}$-ray reading or a drug record or something of that sort; it is there and they can refer to it, and as Judge Nourse says, maybe even get it into evidence.

PROFESSOR LOUISELL: I thoroughly agree that sometimes there is much hearsay in hospital records that should not get in despite the modern statutes like our Code of Civil Procedure section 1953(f). But I do not think that the line is necessarily properly drawn between opinion and other items of evidence. There have been cases, I think, where legitimate opinion, pro-

10 CAL. CODE Crv. Proc. \$1953(f): "A record of an act, condition or event, shall, in so far as relevant, be competent evidence if the custodian or other qualified witness testifies to its identity and the mode of its preparation, and if it was made in the regular course of business, at or near the time of the act, condition or event, and if, in the opinion of the court, the sources of information, method and time of preparation were such as to justify its admission."

11 Cal. Code Civ. Proc. \$§ 1953 (e)-(h). 
vided it is germane to the diagnosis, can come $\mathrm{m}$ under section 1953(f) in a hospital record. ${ }^{12}$

JUDGE NOURSE: My basis is that opinion is not one of the things set forth in the statute; the opinion of an expert is worth no more than the reasons he gives to support it, and the hospital records will not show his reasons. I believe all witnesses expressing an opinion should be subject to cross-examination.

PROFESSOR LOUISELL: That gets to involve the whole history of that particular section. ${ }^{13}$

JUDGE NOURSE: I know it does. As to whether X-rays should be sent into the jury room, the court has discretion by statute to determine what exhibits go to the jury room. It seems to me that a great many doctors cannot read an X-ray, and I do not know of any layman that can. I feel it is up to the jury to listen to the testimony of the experts and not take the $\mathrm{X}$-rays in with them.

PROFESSOR LOUISELL: I realize that what you say is undoubtedly correct under the existing law but I think section 612 of the Code of Civil Procedure $\mathrm{P}^{14}$ is a little too restrictive as to what a jury may see. It seems to me that a jury should be given more right to decide what it wants to see including, generally, all exhibits that have been introduced in evidence. Of course depositions are in a separate category.

\section{QUESTION: Should jurors be allowed to question witnesses?}

JUDGE NOURSE: In my view, that should never be allowed. If jurors try to do it in my court, I ask them to address their questions to me, and if the question seems pertinent I will put it to the witness; if it is immaterial I just tell the jurors it is not involved in the case. I feel I have the onus of relieving counsel froin having to object to a juror's question and shutting him off. Of course, if I do question the witness to meet the juror's question, then I permit counsel to further examine the witness on the same question.

MR. FARGO: I think the trial judge ought to be very brisk in taking charge of the situation where a juror shoots a question. It is embarrassing

12 See, e.g., People v. Kohlmeyer, 284 N.Y. 366, 31 N.E.2d 490 (1940). Contra, New York Life Ins. Co. v. Taylor, 147 F.2d 297 (D.C. Cir. 1945).

13 For discussion of the history and construction of acts providing for the admissibility of business and hospital records, see Palmer v. Hoffman, 318 U.S. 109 (1943); McCorarick, Evmence $\$ 290$ (1954); WrtKIn, CaIIFORnIa Evmence $\$ 292$ (1958).

14 CAI. Code Crv. Proc. $\$ 612$ : "Upon retiring for deliberation the jury may take with them all papers which have been received as evidence in the cause, except depositions, or copies of such papers as ought not, in the opimion of the court, to be taken from the person having them in possession; and they may also take with them any exhibits which the court may deem proper, notes of the testimony or other proceedings on the trial, taken by themselves or any of them, but none taken by any other person." 
for trial counsel to make an objection to a juror's question, and most of them are poorly framed if they are material at all. I think the judge should be awfully alert to leap in there and insist upon the question being directed to the court and then slanted to the witness, if it is a proper question.

QUESTION: How far should the court engage in the interrogation of witnesses?

JUDGE NOURSE: I'm going to leave this to Mr. Fargo to develop; I will say only this-in my opinion a trial is not a sporting event and the trial judge should be something inore than a referee just calling fouls and telling counsel to break clean.

MR. FARGO: I agree with you, Judge Nourse. No matter how much of an adversary proceeding we think we have, we are trying and every good judge is trying to get a proper, just result. But I think this is a touchy subject and one that is not reviewed often enough by the bench. Many judges do not think they are butting into a trial when they question a witness once in a while or open up some subject that the lawyers would prefer remained closed; they feel they are just bringing things out that should be known. The problem is that there is a jury there. I think the general rule should be that the judge ought not, with three factual exceptions, to inake inquiry of any witness. The first exception is where there is an experienced, unprincipled witness that is not being adequately cross-examined, and where if the judge does not interrogate, a miscarriage of justice will result. The second exception will be the situation where there is a frankly evasive or impertinent type of witness which, again, your trial counsel is not sufficiently adept to handle. If the judge does not step into this type of situation, he may lose control of the case. The third exception is an elastic one and arises when there is an important field in the case that the judge feels is not being properly explored. This is where I disagree with my friends on the bench that I have had the temerity to talk to frankly about judge's questions. The only time I would have a trial judge take on inquiry of witnesses when he feels that some area is not being explored is where there is either want of skill on the part of the examiner or there is some gulf between the examiner and the witness that is just not being bridged. Those situations ought to be rare. Many times there are very excellent reasons that the judge does not know anything about why this inquiry should not be pursued. I think the judge ought to be extremely reluctant to carry on his own interrogation, even in this third situation where he thinks there is something that is not being adequately developed.

PROFESSOR LOUISELL: This, to me, is one of the hardest fields about which to generalize with any degree of certainty. I suppose the reason for this is that it represents the ultimate clash between the adversary philosophy on the one hand and the notion of inpartial administration of justice 
by a neutral expert on the other. To me, one of the most pertinent considerations in trying to solve what really is a dilemma is the relative experience of counsel. If you have two highly experienced trial lawyers, each in obvious command of his case, both thoroughly prepared, then I agree that the occasion for extensive intervention by the judge should be very rare indeed. But if I saw one competent trial lawyer making mince meat out of one of my recent graduates, I must admit that the urge to try to balance would probably be a very dominant urge within me. It is one of the hardest things to generalize about, and it is one of those things that really points up why the most important person im the whole system is the competent and fair trial judge.

JUDGE NOURSE: I think that the true purpose of the trial is to ascertain the truth and if the counsel are not getting it from a witness because he is lying, holding back or has a variable inemory, the judge should step in and interrogate.

QUESTION FROM THE FLOOR: Do lawyers feel the same way about judges' interrogating in a trial by the court?

MR. FARGO: There is no objection in a non-jury trial to having a judge interrogate witnesses. This way you get an idea of where the wind is blowing. I was talking about the effect upon the jurors of the judge's interrogation.

QUESTION FROM THE FLOOR: If the judge feels there is some great void in the case, what do you think of the practice of calling counsel up and asking him if the omission is intentional?

MR. FARGO: I think that is a very fair, wise thing to do. It never occurred to me as a solution, but now that you mention it, I do recall judges having done that with profit. My complaint is where you get a judge blindly blundering into an area that any lawyer, if asked, would say to avoid.

QUESTION FROM THE FLOOR: If the judge does interrogate, should he intervene during counsel's examination or at the close of the examination?

JUDGE NOURSE: Except in the one case where you have a recalcitrant witness who just will not answer, the court should wait until counsel are through direct examination, cross-examination and redirect to see if counsel will not develop the matter. It is only when the counsel has failed that the court should ever step in.

PROFESSOR LOUISELL: Even in court tried cases, it seems to me a lot of time is often wasted by the judge stepping in prematurely. Usually counsel have a plan or outline of their presentation, and the judge will save time by permitting things in the first instance to go on as scheduled by the lawyers. 